\title{
Nitrogen versus phosphorus enrichment of brackish waters: responses of the submersed plant Potamogeton perfoliatus and its associated algal community
}

\author{
Janet V. Neundorfer* , W. Michael Kemp** \\ University of Maryland System, Center for Environmental and Estuarine Studies, Horn Point Environmental Laboratory, \\ Cambridge, Maryland 21613, USA
}

\begin{abstract}
We examined the relative effects of nitrogen $(N)$ versus phosphorus $(P)$ enrichment to waters overlying the submersed plant Potamogeton perfoliatus L. and its associated community. This plant species was formerly an abundant component of brackish waters of Chesapeake Bay (USA) prior to a general decline in submersed plants associated with eutrophication. An experimental study was conducted using plant-sediment microcosms held in temperature-controlled baths under natural light in greenhouse facilities. The experimental design consisted of $N$ additions at 2 levels, simulating the range of loading rates to the Bay, and $N$ : $P$ ratios at 3 levels, representing a variety of input conditions from runoff $(N: P=50)$ to sewage effluents $(N: P=2)$. Additions of both $N$ and $P$ caused significant increases in biomass accumulation of epiphytic and phytoplanktonic communities. The effects of $\mathrm{N}$ and $P$ on algal densities were synergistic in that responses to $N$ addition were greatest at high $P$ loading and visa versa. At the highest nutrient treatment rates, combined amendments ( $N$ plus $P$ ) resulted in significantly greater increases in epiphytes and phytoplankton than did the same high inputs of either nutrient ( $\mathrm{N}$ or $\mathrm{P}$ ) individually. Associated with increased algal densities at high nutrient loading rates, there were significant decreases in growth and biomass of $P$. perfoliatus. Again, responses of plant growth to nutrient treatments were most pronounced when both $N$ and $P$ were added together. Pooling data from all treatments, significant inverse correlations were found between epiphyte density and plant growth and biomass as well as light (PAR) attenuation. A hyperbolic relation between PAR attenuation by epiphytes and plant growth suggests light availability as a principal mechanism for epiphytic inhibition of $P$. perfoliatus growth. In addition, plants at high nutrient treatments exhibited morphological responses characteristic of shade adaptation in this species, further emphasizing the importance of light attenuation as a control mechanism. These results suggest that the experimental plant communities were poised in a condition where both $\mathrm{N}$ and $\mathrm{P}$ were potentially limiting for algal growth. Previous studies have attributed the loss of submersed plants from Chesapeake Bay's brackish waters largely to nutrient enrichment. The present results suggest that management efforts to restore submersed plants such as $P$. perfoliatus by reducing eutrophication, and associated light attenuation by algae, should consider reducing inputs of both $\mathrm{N}$ and $\mathrm{P}$.
\end{abstract}

\section{INTRODUCTION}

Submersed vascular plants are a conspicuous and highly productive element of shallow coastal marine ecosystems (Zieman \& Wetzel 1980). Their influences on the physical (Ward et al. 1984) and biogeochemical

\footnotetext{
- Present address: US Army Corps of Engineers, Baltimore District, PO Box 1715, Baltimore, Maryland 21203-1715, USA

- Addressee for correspondence
}

(Caffrey \& Kemp 1990) processes of these systems, as well as their relationship to secondary production (Lubbers et al. 1990) have been well documented. Significant worldwide declines in submersed plant populations have been reported for several decades (den Hartog \& Polderman 1975, Silberstein et al. 1986). The widespread reductions in abundance of these ecologically and socio-economically valuable plant resources stimulated considerable research effort to explain the losses. The results of this research have strongly implicated cultural eutrophication as a key 
factor contributing to the losses of submersed plants (Phillips et al. 1978, Twilley et al. 1985, Cambridge et al. 1986).

Reduced light availability appears to be one of the primary mechanisms by which the eutrophication process affects submersed plant survival (Sand-Jensen \& Søndergaard 1981). Increased inputs of the macronutrients, nitrogen $(\mathrm{N})$ and phosphorus (P), associated with agricultural runoff and sewage treatment outfalls, enhance the growth of both planktonic (Jupp \& Spence 1977, Boynton et al. 1982) and epiphytic (Borum 1985) algae. Both these algal forms reduce the quantity and spectral quality of light transmitted to the surface of submersed plant leaves (Sand-Jensen \& Borum 1984).

To date, much of the research on the effects of anthropogenic nutrient inputs on submersed plant growth and survival has focused on increases of combined nutrient ( $N$ plus P) inputs (Borum 1985, Twilley et al. 1985), with little exploration of the relative effects of $\mathrm{N}$ vs $\mathrm{P}$. While the relative importance of $\mathrm{N}$ vs $\mathrm{P}$ inputs on interactions between submersed plants, epiphytes and phytoplankton depends on the ambient nutrient availability within a given ecosystem, some general patterns might be expected. In most freshwater systems, phytoplankton productivity is P-limited (Schindler 1977), while phytoplankton in coastal marine systems appear to be generally $\mathrm{N}$-limited (Ryther \& Dunstan 1971). It appears that $N$ limitation displaces P limitation for phytoplankton as one moves along estuarine salinity gradients from more brackish to more marine environments (Caraco et al. 1987). Such patterns have not been described for $N$ vs $P$ limitation of epiphytic growth on submersed plants, nor on how interactions among phytoplankton, epiphytes and submersed plants would vary with changes in inputs of $\mathrm{N}$ and/or P.

In the present study we examine the responses of an estuarine population of the submersed plant Potamogeton perfoliatus $\mathrm{L}$. and its associated epiphyte and phytoplankton communities to enrichment with $\mathrm{N}$ and $P$ in experimental microcosms. Until a recent regional decline in submersed plants (Orth \& Moore 1983), $P$. perfoliatus had been an abundant species in brackish portions of Chesapeake Bay, USA (Stevenson \& Confer 1978)

\section{MATERIALS AND METHODS}

\section{Experimental system and design}

Experiments were conducted in a greenhouse facility on the eastern shore of Chesapeake Bay (Cambridge, Maryland, USA). Experimental units consisted of 24 clear acrylic microcosms $(15.2 \times 15.2 \mathrm{~cm}$ base $\times 61 \mathrm{~cm}$ height) containing 6 I of artificial seawater made with deionized water and aquarium salt (Instant Ocean). Each microcosm contained a plastic pot (15 cm diam., $15.2 \mathrm{~cm}$ height) filled with sediment collected from a sparsely vegetated area of the Choptank River estuary known locally as Dickinson Bay. Approximately 400 Potamogeton perfoliatus rhizome segments, each 3 to $5 \mathrm{~cm}$ in length with a 2 to $4 \mathrm{~cm}$ shoot attached, were collected from an experimental estuarine pond (Twilley et al. 1985) on 14 July 1988. Into the sediments of each pot, 15 individual rhizome-shoot segments were inserted.

Twenty-four microcosms were distributed randomly into 2 large water baths filled with chilled recirculating estuarine water to maintain microcosm water temperature within $3{ }^{\circ} \mathrm{C}$ of ambient conditions. Plants were acclimated to experimental systems for $4 \mathrm{wk}$ prior to initiation of treatments. Mean irradiance levels, measured at 12:00 h (noon) at the sediment surface of microcosms on 2 occasions during the acclimation period, ranged from 400 to $440 \mu \mathrm{E} \mathrm{m}^{-2} \mathrm{~s}^{-1}$, with no consistent relation to treatment. Water in all microcosms was bubbled continuously with airstones to provide mixing and to minimize $\mathrm{CO}_{2}$ limitation and $\mathrm{O}_{2}$ inhibition (Kemp et al. 1986). Temperature and salinity in experimental units, which were monitored daily using a total immersion thermometer and a refractometer (Reicher, Model 10419), ranged from 19 to $25^{\circ} \mathrm{C}$ and 12 to $16 \mathrm{ppt}$, respectively. To maintain constant salinity and uniform water levels in microcosms, water lost due to evaporation was replaced with deionized water.

At weekly intervals, sides of each microcosm were cleaned of periphytic materials by scraping with a razor blade. Loosened periphyton was left in the microcosms to avoid uneven alterations of nutrient budgets in the experimental systems. Epibenthic macroinvertebrate herbivores were removed from all microcosms to avoid non-uniform algal grazing rates among treatments.

The experimental design, based on a $2 \times 3$ factorial scheme with $2 \mathrm{~N}$ input rates and 3 ratios of $\mathrm{N}$ : P loading, consisted of 6 nutrient treatments, each with 4 replicates. The 3 ratios in this design were based on: the low end of the range reported for sewage effluents $(2: 1$; Officer \& Ryther 1980); typical values for urban runoff (15:1; Likens 1975); and the upper end of the range for agricultural runoff (50:1; Likens 1975). N loading rates (low and high) were chosen to represent current conditions in different regions of Chesapeake Bay, where high $\mathrm{N}$ inputs generally correspond to small embayments surrounded by large watersheds (Correll 1981), while relatively lower $\mathrm{N}$ inputs represent the open Bay waters (Nixon 1987). Experimental systems were treated with 2 levels of nitrogen, low

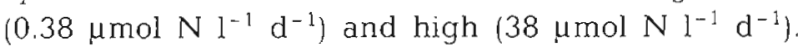


Within each $\mathrm{N}$ level, $\mathrm{P}$ treatments were varied $(0.008$, 0.025 and $0.19 \mu \mathrm{mol} \mathrm{Pl}^{-1} \mathrm{~d}^{-1}$ in low treatments, and

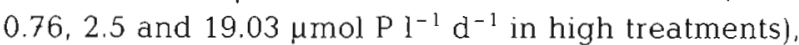
producing 3 distinct $N: P$ loading ratios of $50: 1,15: 1$ and $2: 1$. Microcosms were held in batch culture, with nutrients injected by syringe into the water column every $2 \mathrm{~d}$ from separate aqueous solutions of ammonium nitrate $\left(\mathrm{NH}_{4} \mathrm{NO}_{3}\right)$ and sodium phosphate $\left(\mathrm{NaH}_{2} \mathrm{PO}_{4}\right)$. Treatments continued for $7 \mathrm{wk}$ from 11 August to 30 September 1988.

Experimental systems were sampled periodically over the course of the study. Growth of Potamogeton perfoliatus was measured midway (1 September) through the treatment period and again at the end of the experiment. The same sampling schedule was used to determine epiphyte accumulation on plant leaves, measured as density of chlorophyll $a$, and for attenuation of photosynthetically active radiation (PAR) by epiphytes. Plants were sampled 3 times during nutrient dosing to determine leaf chlorophyll a concentration. Rates of community production and respiration in each experimental unit were measured at the end of the fourth experimental week (8 September). At the end of the experimental period, plant leaves were examined for taxonomic analysis of the epiphytic community. At this time, P. perfoliatus was sampled for above- and below-ground biomass and for tissue $\mathrm{N}$ and $\mathrm{P}$ content.

\section{Experimental methods}

Epiphytic biomass and taxonomic identification. Epiphyte biomass was measured as chlorophyll a. One leaf was removed from 3 representative plants in each replicate treatment at 3,5 and $7 \mathrm{wk}$ after inception of nutrient dosing. To insure relatively uniform age of leaves sampled, plants of approximately equal length were chosen and the fourth youngest leaves were selected by counting down from the plant apical meristem. The leaves were pooled and epiphytes were gently scraped from both sides with a razor blade into filtered artificial seawater at 14 ppt. Microscopic examination of scraped leaves showed an effective removal of all epiphytic material except for a few adnate diatoms. Algal suspensions were filtered, using $2.5 \mathrm{~cm}$ Whatman GF/F $(1.2 \mu \mathrm{m})$ filter pads over a vacuum of $300 \mathrm{~mm}$ of mercury. Filter pads were then wrapped in aluminum foil and stored in sealed plastic bags at $0{ }^{\circ} \mathrm{C}$ for later pigment analysis. Within 6 mo of sampling date, chlorophyll a was extracted (for $24 \mathrm{~h}$ in $90 \%$ acetone) from the frozen filters (Strickland \& Parsons 1972) and read on a Turner (Model 111) fluorometer, which had been calibrated against a Cary (Model 219) spectrophotometer. Chlorophyll a values were corrected for pigment degradation products.
Taxonomic identification of the epiphytic community was made at the conclusion of the 7 wk treatment period. One leaf (fourth from meristem) was removed from each replicate treatment. Epiphytes were scraped into filtered artificial seawater, preserved with gluteraldehyde and stained with DAPI (4'6-diamidino-2phenylindole), a fluorescing dye that enhances visualization and counting of bacteria and cyanophytes (Porter \& Feig 1980). Identification and counts of epiphytes were made using a Zeiss epifluorescent microscope. Each sample consisted of 10 randomly selected fields counted for each slide.

Light attenuation by epiphytes. Prior to filtering, epiphytes scraped from plant leaves into filtered artificial seawater were transferred to $20 \mathrm{ml}$ glass scintillation vials, capped and shaken vigorously to produce a homogeneous suspension. Attenuation of PAR by the epiphytes was then determined using a modification of the method of Borum \& Wium-Andersen (1980). Light was measured with a (LI-COR Model 100-32) irradiance meter fitted with a cosine sensor (Model 192SA) as it passed vertically through a small petri dish containing the homogenized algal suspension. The area of the petri dish was $19.6 \mathrm{~cm}^{2}$, while $9.3 \pm 0.4 \mathrm{~cm}^{2}$ was the mean area of 3 leaves scraped for epiphytes. A linear relation between PAR exponential attenuation coefficient (not attenuation per se) and epiphytic chlorophyll a was assumed to apply in estimating actual PAR attenuation by experimental communities (Borum \& WiumAndersen 1980)

Water column nutrients and chlorophyll. At 2 wk intervals, both immediately before and $1 \mathrm{~h}$ after nutrient additions, a $50 \mathrm{ml}$ syringe was used to take water samples near the center of each experimental microcosm for determination of $\mathrm{NH}_{4}{ }^{+}$and $\mathrm{PO}_{4}{ }^{3-}$ concentration. Aliquots $(10 \mathrm{ml})$ were filtered through $2.5 \mathrm{~cm}$ Whatman GF/F $(1.2 \mu \mathrm{m})$ filters in a Gelman filter holder, and placed in $12 \mathrm{ml}$ plastic sample vials. Vials were capped and frozen immediately at $0^{\circ} \mathrm{C}$. On 2 occasions, microcosm water was sampled for nutrient concentrations at 4 to $8 \mathrm{~h}$ intervals over $36 \mathrm{~h}$. Within 2 mo of sampling dates, vials were thawed and water samples were analyzed for ammonium and phosphate concentrations using autoanalyzer techniques (Parsons et al. 1984). Phytoplankton biomass (as chl a) was measured at Weeks 3 and 7 of the treatment period using $100 \mathrm{ml}$ water samples. Samples were filtered and analyzed for chlorophyll $a$ as described above for epiphytic algae.

Plant biomass and tissue nutrient analysis. At the conclusion of the experimental period, all Potamogeton perfoliatus shoots were removed from each microcosm, rinsed in fresh water and dried to constant weight at $60^{\circ} \mathrm{C}$ to provide a measure of above-ground biomass. Sediments from each microcosm were sieved 
to remove all rhizomes, roots and tubers, which were also rinsed and dried to determine below-ground biomass.

One shoot was removed from each microcosm for tissue nutrient analysis. Shoots of similar length with approximately the same number of leaves were selected. The shoots were placed in filtered artificial seawater and shaken to remove epiphytic material, then rinsed in deionized water and dried to constant weight. Weight of each dried shoot was then recorded and added to weights for above-ground biomass. Each dried shoot was ground with a mortar and pestle and 2 aliquots $(0.2 \mathrm{mg}$ each) were weighed for nutrient analysis. One aliquot was used for carbon and nitrogen analysis (Perkin-Elmer CHN analyzer). The second aliquot was digested in potassium persulfate (Short et al. 1985) and the resulting extract was analyzed for $\mathrm{PO}_{4}{ }^{3-}$ concentration on a Shimadzu UV120-02 spectrophotometer (Parsons et al. 1984).

Plant growth, morphology and pigments. After the acclimation period, randomly selected Potamogeton perfoliatus shoots ( 5 to 7 ) in each microcosm were measured for initial slem length, number of leaves and leaf lengths and widths. To enable sequential observations of growth, each shoot was tagged with a number. Tags were fine-gauge, plastic-coated wire, approximately $10 \mathrm{~cm}$ long, twisted to form a loop at one end. Each loop was tied with a numbered plastic strip and bent to form a $90^{\circ}$ angle with the free end of the wire. A loop was gently placed over the top of each plant, slipped down the stem, and the free end of the wire was inserted into the sediment. At Weeks 3 and 7 of the experiment, the same stem and leaf measurements were made on the tagged plants. To provide additional means for determining plant growth in each micro$\operatorname{cosm}$, the number of new shoots and their total stem length was recorded on both sampling dates.

At the time of each growth measurement, mean internodal length (distance between leaves) was estimated for all marked shoots. Leaf morphology was characterized by selecting and removing one leaf (fourth from meristem) from a shoot in each replicate treatment. Leaf length and width were noted, and areas of fresh leaves were measured using a LI-COR (Model 3100) area meter Biomass of selected leaves was measured after drying to constant weight at $60{ }^{\circ} \mathrm{C}$ to estimate specific leaf area (SLA; area : biomass).

Chlorophyll a concentration was also measured for selected plant leaves. Leaves were scraped free of epiphytic material, and a hole-punch was used to remove a disk ( $6 \mathrm{~mm}$ diam.) of tissue from the center of each leaf (Staver 1984). Disks were placed in aluminum foil packets, sealed in plastic bags and frozen at $0{ }^{\circ} \mathrm{C}$ for later pigment analysis. Chlorophyll a was extracted from leaf disks in test tubes containing $5 \mathrm{ml} 90 \%$ ace- tone and held in dark at $0{ }^{\circ} \mathrm{C}$ for $48 \mathrm{~h}$. At the end of the extraction period, tubes were removed from the freezer and the extract made up to $10 \mathrm{ml}$ with $90 \%$ acetone. Fluorescence was read on a Turner (Model 111) fluorometer before and after acidification with $5 \% \mathrm{HCl}$.

Community production and respiration. Midway through the treatment period, net community production was measured in each experimental unit. After removing the airstones and allowing the microcosms to incubate overnight without bubbling, $\mathrm{O}_{2}$ was measured at a depth of $0.3 \mathrm{~m}$ ( $10 \mathrm{~cm}$ above the plant canopy) approximately every $2 \mathrm{~h}$ beginning at 15 to $30 \mathrm{~min}$ after sunrise for a period of 13 to $14 \mathrm{~h}$, and again on the following morning just before sunrise, to estimate respiration. $\mathrm{O}_{2}$ measurements were made using polarographic electrodes (Orbisphere Laboratories, Geneva, Model 2607) calibrated daily in air. Rates, which were corrected for air-sea gas exchange, were computed from diel excursions in $\mathrm{O}_{2}$ concentration (Twilley et al. 1985).

\section{RESULTS}

\section{Nutrient concentrations}

After 4 wk of treatment, mean water column $\mathrm{NH}_{4}{ }^{+}$ concentrations were $0.5 \mu \mathrm{M}$ and $1.7 \mu \mathrm{M}$ in low and high treatment microcosms, respectively, just prior to dosing. On the same occasion, mean $\mathrm{PO}_{4}{ }^{3-}$ concentrations were $0.1 \mu \mathrm{M}, 0.9 \mu \mathrm{M}$ and $23.8 \mu \mathrm{M}$ for the $50: 1$, $15: 1$ and $2: 1 \mathrm{~N}:$ P ratio treatments, respectively. For all treatments, dissolved inorganic nutrient concentrations declined rapidly following nutrient additions. Within 6 h after dosing, water column $\mathrm{NH}_{4}{ }^{+}$concentrations were reduced by an average of $75 \%$, and within $24 \mathrm{~h}, \mathrm{NH}_{4}{ }^{+}$concentrations were less than $5 \%$ of initial values. Phosphate concentrations responded similarly, with the exception that in High $\mathrm{N} / 2: 1$ treatments an average of $20 \%$ of the initial $\mathrm{PO}_{4}{ }^{3-}$ concentrations were still present $24 \mathrm{~h}$ following dosing.

\section{Epiphyte densities and light attenuation}

Densities of epiphytic algae on plant shoots were low (0.5 to $0.6 \mu \mathrm{g} \mathrm{cm}^{-2}$ leaf) in Low $\mathrm{N}$ treatments, with no significant effect of $N: P$ ratio treatment (Fig. 1a). On plant shoots in High $N$ treatments, however, epiphytic algal densities were significantly greater (by 3 to 5 times) than on shoots in Low $N$ treatments. Additionally, for High $\mathrm{N}$ treatments an inverse relationship between treatment $\mathrm{N}: \mathrm{P}$ ratio and epiphytic algal density was evident, with densities at the 50:1 treatment being significantly $(p<0.03)$ less than those 

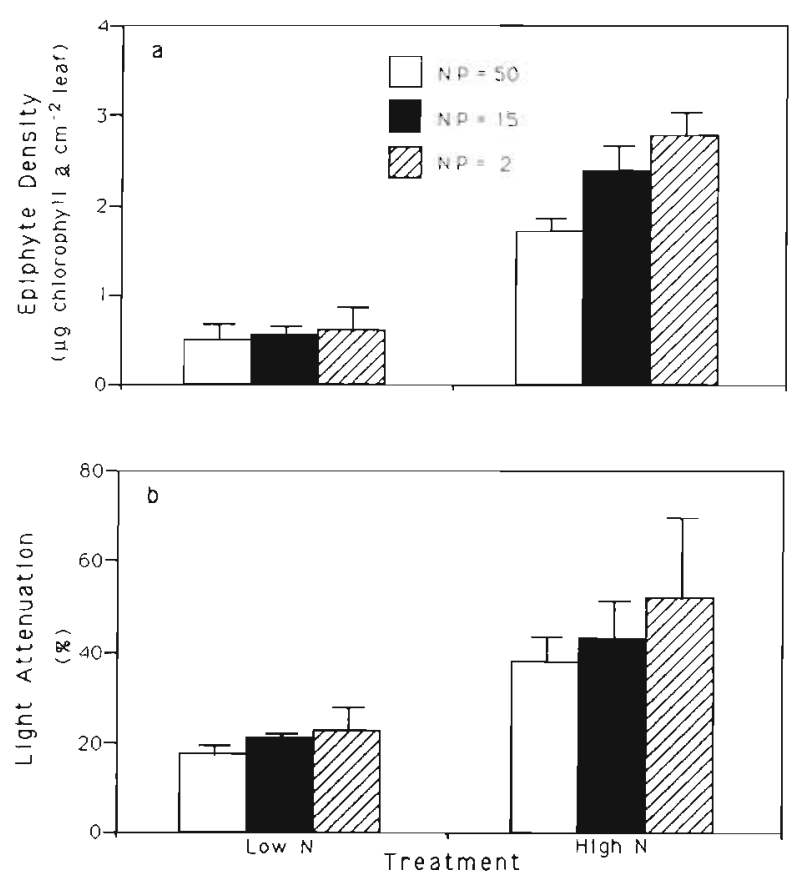

Fig. 1. Responses of (a) epiphyte densities measured as chlorophyll a on Potamogeton perfoliatus leaves and (b) PAR attenuation by epiphytic material on plant leaves to nutrient treatments (after $3 \mathrm{wk}$ ) with experimental $\mathrm{N}$ and $\mathrm{N}$ : P loading rates to microcosm water columns. Values are means \pm SE for $\mathrm{n}=4$ replicates in each treatment

at the lower ratios. Attenuation of PAR associated with epiphytic material on plant leaves was significantly (ANCOVA, p $<0.05$ ) related to epiphyte chlorophyll a densities (Fig. 2a). PAR attenuation increased significantly $(p<0.01)$ with increased nitrogen treatment from Low $N$ to High $N$. As with epiphyte density, PAR attenuation appeared to increase with decreased $N: P$ ratio (Fig. 1b); although this pattern was striking, it was not statistically significant.

\section{Epiphyte community composition}

Following 6 wk of $N$ and $P$ enrichment of the overlying water, the epiphytic communities that developed under different nutrient treatments exhibited several distinct patterns (Table 1). In terms of numbers of cells per leaf area, bacteria dominated the epiphytic community in all treatments. Numbers of bacteria in High $\mathrm{N}$ treatments were $20 \%$ greater than in Low $\mathrm{N}$ treatments; however, no effect of $\mathrm{N}$ : $\mathrm{P}$ ratio was evident on numbers of bacteria in either Low $\mathrm{N}$ or High $\mathrm{N}$ treatments. Apart from bacteria, diatoms were 2 to 3 times more numerous than the remaining 3 components defined for the epiphytic community (cyanophytes, unicellular chlorophytes and multicellular chlorophytes) in all Low $\mathrm{N}$ treatments. Within Low $\mathrm{N}$ treatments, all
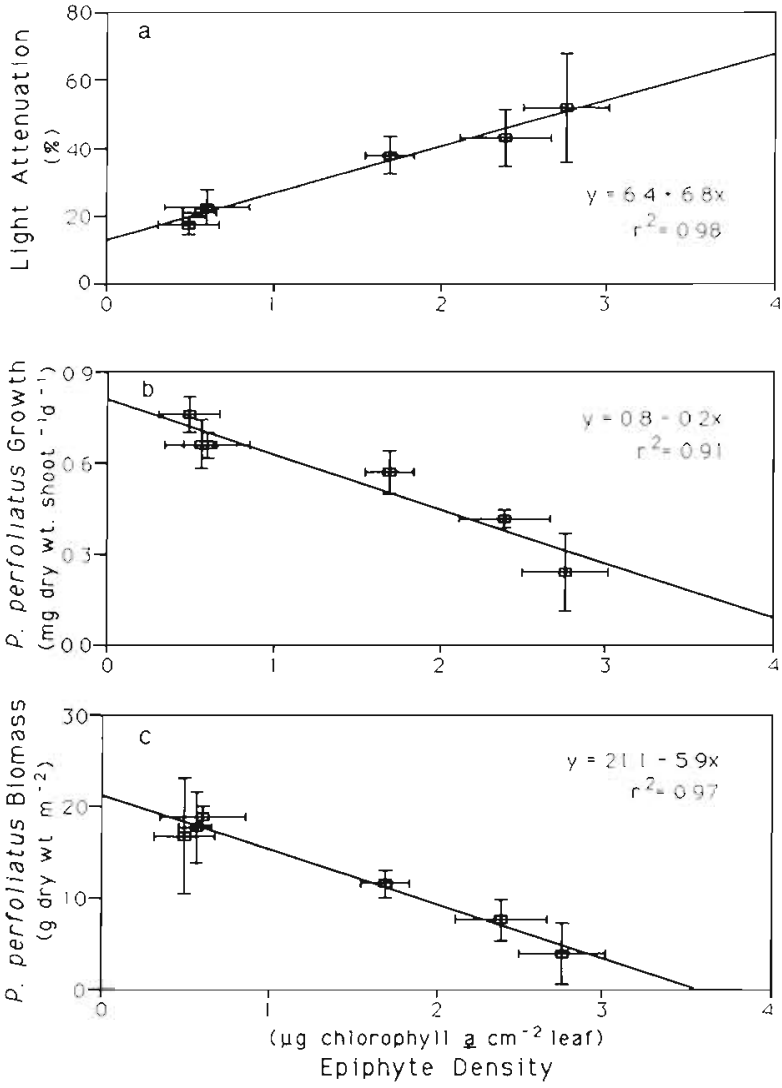

Fig. 2. Correlations between densities of epiphytic chlorophyll a and: (a) PAR attenuation by epiphytic material; (b) growth of Potamogeton perfoliatus; and (c) P. perfoliatus biomass. Data pooled from all treatments, with means \pm SE plotted

components of the epiphytic community were most numerous in the 15:1 N:P ratio treatment. In High $N$ treatments, however, numbers of diatoms, cyanophytes and bacteria were lowest in 15:1 N:P ratio treatments. Diatoms were the dominant algal component of the epiphytic community in both High N/50:1 and High N/2:1 treatments. Only multicellular chlorophytes exhibited an N:P ratio effect within High $N$ treatments, such that numbers decreased as $N: P$ ratio decreased, though the differences were not statistically significant.

\section{Plant morphology and tissue composition}

Within 3 to 6 wk of initiation of $\mathrm{N}$ and $\mathrm{P}$ additions, Potamogeton perfoliatus exhibited substantial changes in several morphological and physiological parameters. In all nutrient treatments, leaf length: width ratio (mean values between 4.1 and $4.7 \mathrm{~cm} \mathrm{~cm}^{-1}$ ) increased by a factor of about 2 over the mean length: width ratio for leaves of pretreatment plants $\left(2.1 \pm 0.04 \mathrm{~cm} \mathrm{~cm}^{-1}\right)$. 
Table 1. Composition of epiphytic community growing on Potamogeton perfoliatus leaves following 6 wk of water column enrichment with nitrogen and phosphorus

\begin{tabular}{|c|c|c|c|c|c|}
\hline Treatment & Diatoms ${ }^{4}$ & Cyanophytes & $\begin{array}{l}\text { Unicellular } \\
\text { chlorophytes }^{d}\end{array}$ & $\begin{array}{l}\text { Multicellular } \\
\text { chlorophytes }^{\mathrm{b}}\end{array}$ & Bacteria \\
\hline \multicolumn{6}{|l|}{ Low $\mathrm{N}$} \\
\hline$N: P=50$ & $29.4 \pm 4.2$ & $13.0 \pm 1.1$ & $10.5 \pm 4.6$ & $0.4 \pm 0.4$ & $832.6 \pm 66.0$ \\
\hline$N: P=15$ & $58.9 \pm 25.4$ & $20.6 \pm 3.4$ & $20.6 \pm 1.7$ & $1.3 \pm 0.8$ & $917.6 \pm 146.7$ \\
\hline$N: P=2$ & $21.9 \pm 8.6$ & $8.8 \pm 1.3$ & $12.6 \pm 4.3$ & 0 & $439.4 \pm 38.1$ \\
\hline \multicolumn{6}{|l|}{ High N } \\
\hline$N: P=50$ & $68.5 \pm 38.0$ & $49.6 \pm 32.9$ & $14.3 \pm 3.5$ & $3.8 \pm 1.7$ & $929.6 \pm 168.7$ \\
\hline$N: P=15$ & $7.1 \pm 5.0$ & $32.4 \pm 9.5$ & $34.1 \pm 6.1$ & $1.7 \pm 1.2$ & $730.7 \pm 20.8$ \\
\hline$N: P=2$ & $104.7 \pm 44.4$ & $58.9 \pm 23.1$ & $10.9 \pm 6.4$ & $0.4 \pm 0.4$ & $937.6 \pm 359.6$ \\
\hline
\end{tabular}

There were, however, no significant differences between $\mathrm{N}$ loading rates or among $\mathrm{N}: \mathrm{P}$ ratios. After 3 wk of treatment, specific leaf areas (SLA, ratio of surface area to dry weight) of all treated plants were 2 to 4 times greater than those for pretreatment plants $\left(8.5 \pm 0.8 \mathrm{dm}^{2} \mathrm{~g}{ }^{1}\right)$. SLA of plants in High $\mathrm{N}$ treatments (mean values of 26.1 to $32.6 \mathrm{dm}^{2} \mathrm{~g}^{-1}$ ) were significantly $(\mathrm{p}<0.01)$ greater than in Low $\mathrm{N}$ treatments (means from 20.2 to $21.7 \mathrm{dm}^{2} \mathrm{~g}^{-1}$ ). There was, however, no effect of N:P ratio on specific leaf area. Similarly, $P$. perfoliatus stem internodal lengths (a measure of stem elongation) were 1 to 2 times greater in all treatments relative to pretreatment plants $(4.5 \pm 0.3 \mathrm{~mm})$. Further, internodal lengths in High $\mathrm{N}$ treatments (mean values 9.3 to $10.5 \mathrm{~mm})$ were significantly greater $(p<0.01)$ than in Low $\mathrm{N}$ treatments (means 8.8 to $9.6 \mathrm{~mm}$ ). There was no significant $\mathrm{N}: \mathrm{P}$ ratio effect on internodal length.

Leaf chlorophyll a concentrations were lower in all treatments relative to pretreatment plants $(0.95 \pm 0.1$ $\mu \mathrm{g}$ chl a $\mathrm{cm}^{-2}$ leaf), and lower in High $\mathrm{N}$ treatments

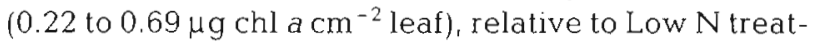
ments ( 0.64 to $0.77 \mu \mathrm{g} \mathrm{chl} \mathrm{a} \mathrm{cm}^{-2}$ leaf). There was no significant treatment $\mathrm{N}$ : $\mathrm{P}$ ratio effect on tissue chlorophyll a concentration. Chlorophyll a concentrations in High N/2:1 treatment plants were, however, substantially lower than in any other treatment.

Potamogeton perfoliatus leaf tissue concentrations of $\mathrm{N}$ and $\mathrm{P}$ also exhibited responses to nutrient enrichment of the overlying water. Initial tissue nutrient levels for the plants used in this experiment were approximately 1.4 to $1.7 \mathrm{mmol} \mathrm{Ng}$ dry $\mathrm{wt}^{-1}$ and 60 to 100 $\mu \mathrm{mol} P \mathrm{~g}$ dry $w^{-1}$ (Twilley et al. 1986). At the end of the treatment period, there were no significant differences in tissue $\mathrm{N}$ concentrations between High $\mathrm{N}$ (mean 1.8 to $2.2 \mathrm{mmol} \mathrm{N} \mathrm{g} \mathrm{dry} \mathrm{wt}^{-1}$ ) and Low $\mathrm{N}$ treatments $\left(1.6\right.$ to $\left.2.2 \mathrm{mmol} \mathrm{N} \mathrm{g} \mathrm{dry} \mathrm{wt}^{-1}\right)$. Within Low $\mathrm{N}$ treatments, however, there was some evidence of in- creasing tissue $\mathrm{N}$ concentration with decreasing $\mathrm{N}: \mathrm{P}$ ratio, although these differences were not statistically significant. Similarly, leaf tissue $P$ concentrations were not significantly different between Low $\mathrm{N}$ (mean 18.7 to $28.4 \mu \mathrm{mol} \mathrm{P} \mathrm{g} \mathrm{dry} \mathrm{wt}^{-1}$ ) and High $\mathrm{N}$ treatments ( 19.7 to $23.6 \mu \mathrm{mol} \mathrm{P} \mathrm{g} \mathrm{dry} \mathrm{wt}^{-1}$ ). Again, these tissue P concentrations appeared to increase with decreased N:P ratio in Low $\mathrm{N}$ treatments, but the differences were not significant. Tissue P concentration in High N/2:1 treatment was 2 to 3 times larger than in any other treatment. Consequently, tissue $\mathrm{N}: \mathrm{P}$ ratios in High $\mathrm{N}$ treatments decreased significantly $(p<0.05)$ with decreasing treatment $\mathrm{N}$ : $\mathrm{P}$ ratio.

\section{Plant growth and standing stock}

Growth of Potamogeton perfoliatus, measured both as above-ground accumulation of dry mass and as emergence of new leaves, decreased as nitrogen treatments increased (Fig. 3a, b). Plant growth (dry wt) in Low $N$ treatments was significantly higher $(p<0.01)$ than that in High $N$ treatments (Fig. 3a). There was no evidence of phosphorus effect on plant biomass growth in Low $\mathrm{N}$ treatments. In High $\mathrm{N}$ treatments, however, there was a significant effect $(p<0.07)$ of $P$, where growth decreased by $25 \%$ and more than $50 \%$ at $N: P$ ratios of $15: 1$ and $2: 1$, respectively, relative to the 50:1 treatment. Similarly, leaf emergence rates in High $N$ treatments were less than $20 \%$ those in Low $N$ treatments (Fig. 3b). In High $\mathrm{N}$ treatments, mean leaf emergence rates were also lower with increased $\mathrm{P}$ additions, although the differences were not statistically significant.

At the conclusion of the 7 wk treatment period, above-ground biomass of Potamogeton perfoliatus was significantly $(p<0.01)$ lower in High $N$ treatments than in Low $\mathrm{N}$ treatments (Fig. 4). Although there were no 

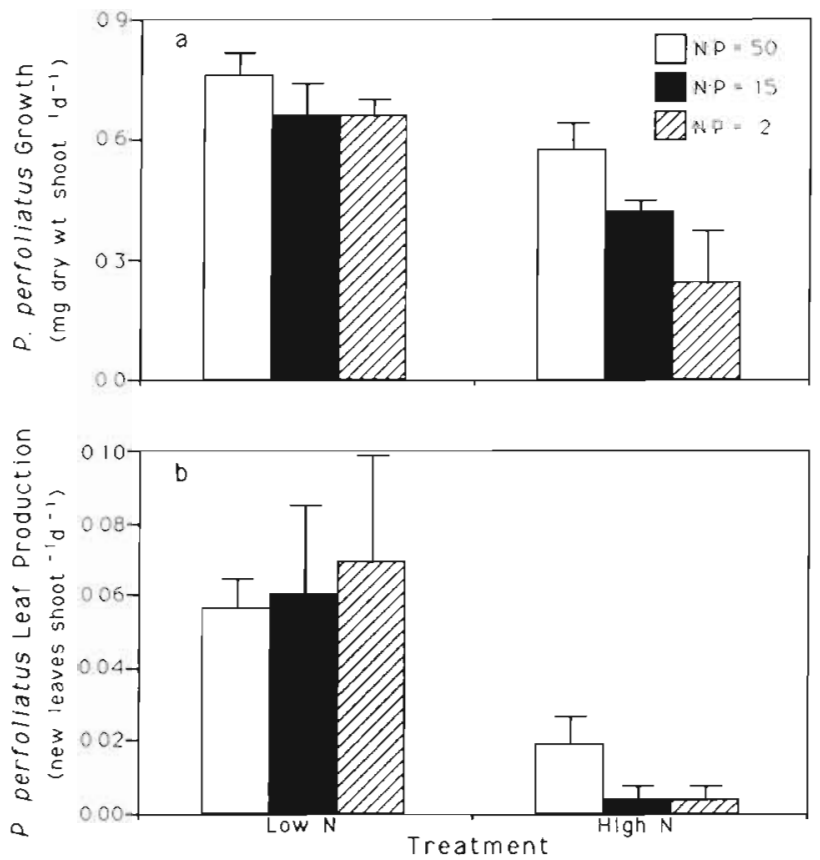

Fig. 3. Responses of Potamogeton perfoliatus growth (mean \pm $\mathrm{SE}, \mathrm{n}=4$ ) to nutrient treatments (after $3 \mathrm{wk}$ ) with experimental $\mathrm{N}$ and $\mathrm{N}$ : $\mathrm{P}$ loading rates to microcosm water columns. Growth measured as (a) increases in dry wt per shoot per day and (b) new leaf production per shoot per day

significant effects of $\mathrm{N}$ : $\mathrm{P}$ ratio on above-ground standing stock among Low $N$ treatments, plant biomass was inversely related to $\mathrm{N}$ : P ratio with High $\mathrm{N}$ treatments. Similar results were exhibited for below-ground plant biomass at the end of the treatment period, with significantly $(p<0.03)$ lower biomass in High $N$ treatments (Fig. 4) than in Low $N$ treatments. There was no $N: P$ ratio effect on below-ground biomass in either Low $N$ or High $\mathrm{N}$ treatments.

Plant growth was inversely related to epiphyte densities. Regression of plant growth versus epiphytic algal density (Fig. 2b) displayed a significant $(p<0.07$ ) relationship. A similar significant $(\mathrm{p}<0.05)$ inverse correlation was apparent in regression of Potamogeton perfoliatus above-ground standing stock versus epiphyte density (Fig. 2c). The direct correlation between epiphyte density and PAR attenuation, which was also observed, suggests shading as a mechanism to explain the inverse relations between plants and epiphytes.

\section{Phytoplankton concentrations and light attenuation}

After 3 wk of nutrient additions to the overlying water, phytoplankton abundance was consistently low (Table 2), with a modest suggestion of increased chlorophyll a concentration with nitrogen loading, and no evidence of $\mathrm{N}$ : P ratio effects. Similarly, attenuation of

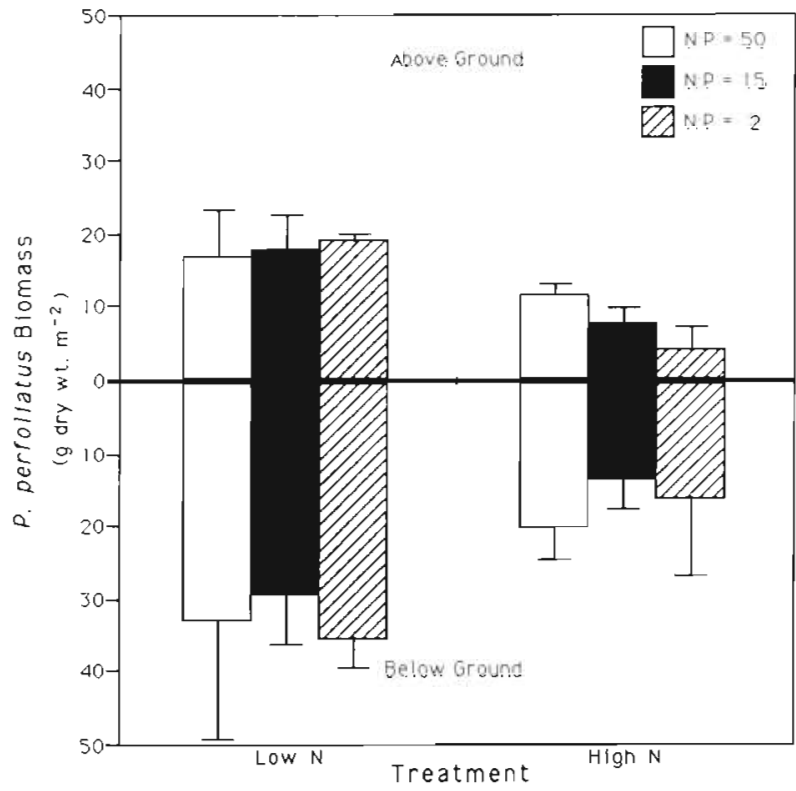

Fig. 4. Responses of Potamogeton perfoliatus biomass (mean $\pm \mathrm{SE}, \mathrm{n}=4$ ) to nutrient treatments (after $6 \mathrm{wk}$ ) with experimental $N$ and $N$ :P loading rates to microcosm water columns. Above- and below-ground biomass values plotted above and below zero line, respectively

PAR by phytoplankton (plus water and other dissolved and particulate materials) on this sampling date was uniformly about $32 \%$. By the end of $6 \mathrm{wk}$ of nutrient additions, however, phytoplankton chlorophyll a concentrations in Low $\mathrm{N}$ treatments had increased 19- to 27 -fold with no effect of $\mathrm{N}$ : P ratio on concentrations. In High $\mathrm{N}$ treatments, phytoplankton chlorophyll a concentrations increased by a factor of 22 to 41 over those at $3 w k$, and were significantly $(p<0.04)$ greater (by 4 to 18 -fold) than concentrations in Low $N$ treatments at $6 \mathrm{wk}$. There was also a significant $(\mathrm{p}<0.05) \mathrm{N}$ : $\mathrm{P}$ ratio effect at $6 \mathrm{wk}$ under High $\mathrm{N}$ treatment. In Low $\mathrm{N}$ treatments, attenuation of PAR by phytoplankton after $6 \mathrm{wk}$ of nutrient enrichment did not increase significantly over attenuation after 3 wk of treatment. However, in High $N$ treatments, PAR attenuation was 15 to $55 \%$ greater compared to the earlier sampling date, and 12 to $52 \%$ greater than attenuation in Low $\mathrm{N}$ treatments at $6 \mathrm{wk}$.

\section{Community production and respiration}

Net community production $\left(\mathrm{g} \mathrm{O}_{2} \mathrm{~m}^{-2} \mathrm{~d}^{-1}\right)$ exhibited significant $(\mathrm{p}<0.01)(2$-fold $)$ increase in response to $\mathrm{N}$ treatments (Table 3). Community respiration rates, however, were only half as great in High $N$ treatments compared to Low $\mathrm{N}$. Consequently, ratios of community production to respiration $(\mathrm{P}: \mathrm{R})$ were 4 to 5 times 
Table 2. Phytoplankton chlorophyll a concentrations and associated percent light (PAR) reduction in microcosms after $3 \mathrm{wk}$ and 6 wk of enrichment with $\mathrm{N}$ and P. Percent PAR reduction was calculated as $100\left(1-\left(I_{z} / I_{0}\right)\right)$ where $I_{z} / I_{0}=\mathrm{e}^{-k|<|} ; k$ is the attenuation coefficient calculated from chlorophyll a concentration (Staver 1984), and $z$ is the height of the water column above the plant canopy

\begin{tabular}{|c|c|c|c|c|}
\hline \multirow[t]{2}{*}{ Treatment } & \multicolumn{2}{|c|}{3 wk enrichment } & \multicolumn{2}{|c|}{$6 \mathrm{wk}$ enrichment } \\
\hline & $\begin{array}{l}\text { Phytoplankton } \\
\left(\mu \mathrm{g} \mathrm{chl} a l^{-1}\right)^{d}\end{array}$ & $\begin{array}{l}\text { Light } \\
\text { reduction } \\
(\%)^{\mathrm{a}}\end{array}$ & $\begin{array}{l}\text { Phytoplankton } \\
\left(\mu \mathrm{g} \mathrm{chl} \mathrm{al}^{-1}\right)^{\mathrm{a}}\end{array}$ & $\begin{array}{c}\text { Light } \\
\text { reduction } \\
(\%)^{\text {s }}\end{array}$ \\
\hline \multicolumn{5}{|l|}{ Low $\mathrm{N}$} \\
\hline$N: P=50$ & $0.1 \pm 0.03$ & $32.3 \pm 0.07$ & $1.9 \pm 0.4$ & $33.2 \pm 0.2$ \\
\hline$N: P=15$ & $0.2 \pm 0.04$ & $32.3 \pm 0.04$ & $2.5 \pm 1.3$ & $33.5 \pm 0.7$ \\
\hline$N: P=2$ & $0.1 \pm 0.02$ & $32.4 \pm 0.05$ & $2.7 \pm 1.0$ & $33.6 \pm 0.5$ \\
\hline \multicolumn{5}{|l|}{ High $N$} \\
\hline$N: P=50$ & $0.6 \pm 0.14$ & $32.5 \pm 0.07$ & $13.2 \pm \quad 4.0$ & $38.5 \pm 1.9$ \\
\hline$N: P=15$ & $0.7 \pm 0.10$ & $32.6 \pm 0.06$ & $10.9 \pm 2.9$ & $37.5 \pm 1.4$ \\
\hline$N: P=2$ & $1.2 \pm 0.21$ & $32.8 \pm 0.09$ & $49.5 \pm 25.4$ & $51.0 \pm 8.0$ \\
\hline
\end{tabular}

under similar nutrient loading conditions in both freshwater (Phillips et al. 1978) and marine (Silberstein et al. 1986) environments. In each of these cases, the reductions in plant growth were ascribed to increased growth of epiphytes and associated PAR attenuation.

Despite decreased growth of Potamogeton perfoliatus in high nutrient treatments (compared to low nutrient conditions), net primary productivity of the total microcosm communities and associated $P: R$ ratios were increased with greater nutrient loading (Week 4). This result may be explained by

greater in High $\mathrm{N}$ treatments than those in Low $\mathrm{N}$ treatments.

\section{DISCUSSION}

\section{Plant growth responses to nutrient enrichment}

In the present study, growth and biomass of Potamogeton perfoliatus showed similar negative responses to high levels of combined $N$ plus $P$ enrichment (Figs. $3 \& 4$ ). Under comparable high nutrient enrichment (approximately $10 \mathrm{mmol} \mathrm{N} \mathrm{m}^{-2} \mathrm{~d}^{-1}, 1 \mathrm{mmol} \mathrm{P}$ $\mathrm{m}^{-2} \mathrm{~d}^{-1}$ ), both Twilley et al. (1985) and Staver (1984) reported decreased above-ground biomass for $P$. perfoliatus, relative to their medium and low treatments and to their controls. Decreased growth and biomass of other submersed plant species have also been reported

Table 3. Community production and respiration after 4 wk of water column enrichment with nitrogen and phosphorus

\begin{tabular}{|cccc|}
\hline Treatment & $\begin{array}{c}\text { Net production } \\
\left(\mathrm{g} \mathrm{O}_{2} \mathrm{~m}^{-2} \mathrm{~d}^{-1}\right)^{d}\end{array}$ & $\begin{array}{c}\text { Respiration } \\
\left(\mathrm{g} \mathrm{O}_{2} \mathrm{~m}^{-2} \mathrm{~d}^{-1}\right)^{d}\end{array}$ & $\mathrm{P}: \mathrm{R}$ ratio \\
\hline Low $\mathrm{N}$ & & & \\
$\mathrm{N}: \mathrm{P}=50$ & $4.0 \pm 0.6$ & $3.9 \pm 0.2$ & $1.0 \pm 0.2$ \\
$\mathrm{~N}: \mathrm{P}=15$ & $3.9 \pm 0.1$ & $3.9 \pm 0.3$ & $1.0 \pm 0.1$ \\
$\mathrm{~N}: \mathrm{P}=2$ & $4.1 \pm 0.2$ & $4.1 \pm 0.1$ & $1.0 \pm 0$ \\
$\mathrm{H}$ & & & \\
$\mathrm{High} \mathrm{N}$ & & & \\
$\mathrm{N}: \mathrm{P}=50$ & $8.0 \pm 0.3$ & $2.0 \pm 0.2$ & $4.1 \pm 0.4$ \\
$\mathrm{~N}: \mathrm{P}=15$ & $7.7 \pm 0.3$ & $1.9 \pm 0.2$ & $4.1 \pm 0.4$ \\
$\mathrm{~N}: \mathrm{P}=2$ & $8.7 \pm 0.5$ & $1.8 \pm 0.2$ & $5.0 \pm 0.6$ \\
& & \\
a Values are means of 4 replicates of each treatment $\pm \mathrm{SE}$ &
\end{tabular}

a shift in dominant primary producers between nutrient treatments. Assuming a dry weight-to-chlorophyll ratio of 100 for epiphytes (Parsons et al. 1979), we estimated that while total plant biomass (submersed plant plus epiphytes) in Week 3 was dominated (70 to $80 \%$ ) by $P$. perfoliatus under low nutrient loading conditions, biomasses of epiphytes (mean, $60 \%$ ) tended to exceed those of the host plant under high nutrient conditions (Neundorfer 1990). Phytoplankton standing stocks were an insignificant component $(<5 \%)$ of the total plant biomass throughout the sampling (Table 2, Weeks 3 and 6). Further, as a percentage of total community standing stock, epiphytes increased from 40 to $75 \%$ as N:P ratio decreased from 50:1 to $2: 1$ at High N loading rates. Although data for epiphyte photosynthesis are not available, it appears from biomass measurements that higher nutrient treatments stimulated epiphyte production, without concomitant increase in community respiration by the time of these measurements (Weeks 3 to 4). Twilley et al. (1985) reported similar stimulation of net $\mathrm{O}_{2}$ production for experimental pond communities containing $P$. perfoliatus at medium nutrient ( $N$ plus $P$ ) amendments, even though plant biomass decreased compared to controls. At high nutrient treatments, however, they found significant decreases in both plant biomass and net community production.

At the highest levels of combined nutrient enrichment (High N, 2:1 ratio), biomasses of both epiphytes and phytoplankton were significantly increased, relative to low nutrient treatments (Low N/50:1 ratio). Borum (1985) also reported increases in both epiphyte and phytoplankton biomass along a nutrient enrichment gradient. Similarly, both Bulthuis \& Woelkerling 
(1983) and Silberstein et al. (1986) observed increased epiphyte biomass at field sites with increased nutrient enrichment compared to control sites. In the presence of epifaunal grazers, rates of epiphyte biomass accumulation with nutrient enrichment might have been substantially retarded, thereby mollifying inhibitory effects on Potamogeton perfoliatus growth (e.g. Van Montfrans et al. 1984, Cattaneo \& Kalff 1986).

\section{Light attenuation and plant growth}

With nutrient enrichment, increased biomasses of both epiphytic and planktonic algae contributed substantially to reductions in PAR available for Potamogeton perfoliatus photosynthesis. While both plankton and epiphytes contributed to PAR attenuation for all experimental systems, only the epiphyte contribution changed significantly with nutrient enrichment (Table 2, Fig. 2; Neundorfer 1990). The strength of the inverse relations between both growth (Fig. 2b) and aboveground standing stock of $P$. perfoliatus (Fig. 2c) and PAR attenuation by epiphytic algae suggests that epiphyte shading played an important role in the observed plant stress. Comparing relative effects of $\mathrm{N}$ treatment (High N vs Low N) on plant growth and on total PAR attenuation for various N:P treatments further suggests the importance of light limitation. The ratio of reductions in plant growth to reduction in PAR available with $\mathrm{N}$ enrichment at high, medium and low $\mathrm{N}$ :P increased from $0.5: 1$ to $0.6: 1$ to $1: 1$. Therefore, on a relative basis, as incident irradiance decreased, the magnitude of reduction in plant growth increased. Specifically, as light levels decreased, the ratio of growth reduction to light attenuation approached a 1:1 relationship, indicating that plant growth under these reduced light conditions was in the linear (initial slope) portion of the photosynthesis-irradiance (P-I) relation (Goldsborough \& Kemp 1988). The fact that this relation between light reduction and plant growth resembles a hyperbolic P-I curve adds support to the inference of light attenuation as a primary mechanism limiting plant growth (Twilley et al. 1985).

In response to the dramatically reduced light conditions in high nutrient treatments, Potamogeton perfoliatus plants in this study exhibited several morphological changes. Both internodal length and specific leaf area exhibited significant increases in response to both $\mathrm{N}$ and $\mathrm{P}$ loading, although the relative effect of $\mathrm{P}$ treatment was greater. These changes are measures of stem elongation and leaf thinning, respectively. Goldsborough \& Kemp (1988) postulated that these morphological changes alter the P-I relationship for P. perfoliatus. Specifically, stem elongation has the effect of moving the apical leaves closer to the water surface, thereby increasing light availability (Barko \& Smart 1981). Similarly, increased ratio of leaf surface area to weight, or leaf thinning, may concentrate light harvesting pigments at the leaf surface where incident light levels are highest, again resulting in increased photosynthesis (Spence 1975). Although these morphological changes would be relatively ineffective in ameliorating shading by epiphytes (Goldsborough \& Kemp 1988), they represent further evidence that nutrient enriched plant communities were light-limited in this study.

In contrast, Potamogeton perfoliatus did not exhibit increased tissue concentrations of chlorophyll $a$ with increased nutrients and associated shading by epiphytes and phytoplankton in our experiment. In fact, leaf chlorophyll a concentrations decreased significantly at the highest $\mathrm{N}$ and $\mathrm{P}$ loading rates. This response would appear to be inconsistent with previous reports that leaf tissue concentrations of chlorophyll a increased when light levels were reduced (Barko \& Smart 1981, Dennison \& Alberte 1986, Goldsborough \& Kemp 1988). If these plants were generally nutrient limited, however, their ability to produce pigments would have been inhibited, especially in that $\mathrm{N}$ is a key constituent of chlorophyll a molecules (Salisbury \& Ross 1985). Pedersen (1990) has provided evidence that chlorophyll a content of eelgrass leaves is commonly N-limited during the plant growing season in Danish coastal waters. In fact, $\mathrm{N}$ content of $P$. perfoliatus leaf tissue was generally $>2 \%$ dry wt for all treatments, suggesting the absence of $\mathrm{N}$ deficiency (Atkinson \& Smith 1983, Duarte 1990). Phosphorus levels in plant tissues ( 0.1 to $0: 2 \%$ dry wt) were, however, well below median values reported for submersed plants $(0.35 \%$ dry wt) indicating possible P limitation (Duarte 1990).

\section{Responses to $\mathrm{N}$ versus $\mathrm{P}$}

The present experiment was designed to examine the response of Potamogeton perfoliatus to $\mathrm{N}$ loading over a range of $\mathrm{N}: \mathrm{P}$ input ratios. While it is also of interest to consider the relative effects of $\mathrm{N}$ vs $\mathrm{P}$ enrichment per se, a direct comparison is complicated by the fact that $P$ inputs at High and Low $N$ treatments were different in order to maintain the same $N$ : $P$ input ratios at both $\mathrm{N}$ loading levels. In addition, the range from low to high $\mathrm{N}$ inputs was 100 -fold, while it was only 25 fold for low to high $P$ inputs. General comparisons of the relative effect of $\mathrm{N}$ vs $\mathrm{P}$ treatment can be made, however, by assuming a linear relationship between loading and response. In this case, we considered that the response to a 25 -fold increase in $\mathrm{N}$ input would have been $25 \%$ of that observed for the 100 -fold increase. Furthermore, since the mean N:P ratio for 
Table 4. Relative responses (\% change) of epiphyte and phytoplankton biomass and Potamogeton perfoliatus growth to 25 -fold (or equivalent) ${ }^{a}$ increase in $\mathrm{N}$ or $\mathrm{P}$ loading

\begin{tabular}{|c|c|c|c|c|}
\hline $\begin{array}{l}\text { Condition } \\
\text { of 'other' } \\
\text { nutrient }\end{array}$ & $\begin{array}{l}\text { Treatments } \\
\text { compared }\end{array}$ & $\begin{array}{c}\text { Epiphyte } \\
\left.\text { ( } \mu \mathrm{g} \mathrm{chl} \mathrm{a} \mathrm{cm}^{-2} \text { leaf }\right) \\
(\% \text { change })\end{array}$ & $\begin{array}{c}\text { Phytoplankton } \\
\left.\text { ( } \mu \mathrm{g} \mathrm{chl} a \mathrm{l}^{-1}\right) \\
\text { (\% change) }\end{array}$ & $\begin{array}{c}\text { P. perfoliatus } \\
\left.\text { (mg dry wt shoot }{ }^{-1} \mathrm{~d}^{-1}\right) \\
(\% \text { change })\end{array}$ \\
\hline \multicolumn{5}{|c|}{ Responses to $\mathrm{N}$ increase $\mathrm{a}^{\mathrm{a}}$} \\
\hline 'P-Poor' & Low N/50:1 vs High N/50:1 & +6 & +148 & -6 \\
\hline 'P-Rich' & Low $N / 2: 1$ vs High $N / 2: 1$ & +90 & +425 & -16 \\
\hline \multicolumn{5}{|c|}{ Responses to $\mathrm{P}$ increase } \\
\hline 'N-Poor' & Low $N / 50: 1$ vs Low $N / 2: 1$ & +22 & +42 & -13 \\
\hline 'N-Rich' & High $N / 50: 1$ vs High $N / 2: 1$ & +62 & +275 & -58 \\
\hline
\end{tabular}

single-cell algae is about 15:1 (Redfield et al. 1963), we refer to treatments at $\mathrm{N}: \mathrm{P}$ of $50: 1$ as 'P-Poor', while treatments at $\mathrm{N}$ : $\mathrm{P}$ of $2: 1$ are referred to as 'P-Rich'. $\mathrm{P}$ effects under 'N-Poor' and 'N-Rich' conditions were addressed similarly by comparing effects at 50:1 and $2: 1$ loading ratios at Low $\mathrm{N}$ and High $\mathrm{N}$ treatments, respectively (Table 4).

Epiphyte biomass exhibited interactive responses to $\mathrm{N}$ and $\mathrm{P}$ enrichment. Under 'P-Poor' conditions, the equivalent of a 25 -fold increase in $\mathrm{N}$ produced a $6.3 \%$ increase in epiphyte density, whereas under 'P-Rich' conditions a 25 -fold increase in $\mathrm{N}$ resulted in more than $90 \%$ increase in epiphytes (Table 4). Thus, in these experiments increased availability of $\mathrm{P}$ resulted in almost 15 times greater response of epiphyte accumulation to $\mathrm{N}$ enrichment. Although $\mathrm{N}$ availability also influenced the magnitude of epiphyte responses to $P$ enrichment, the effects were less pronounced. Under 'N-Poor' conditions, a 25 -fold increase in $\mathrm{P}$ resulted in a $22 \%$ increase in epiphyte biomass, while under 'N-Rich' conditions, the same 25 -fold increase in $\mathrm{P}$ resulted in a $62 \%$ increase in epiphyte chlorophyll a $\mathrm{cm}^{-2}$ leaf.

The pattern of phytoplankton response to $\mathrm{N}$ vs $\mathrm{P}$ additions was similar to that for epiphytic algae, although the magnitude of effects were dramatically larger. A 25 -fold increase in $\mathrm{N}$ produced a $149 \%$ increase in phytoplankton chlorophyll a concentration under 'P-Poor' conditions, and a $425 \%$ increase under 'P-Rich' conditions (Table 4). As was the case for epiphytic algae, $\mathrm{N}$ stimulation of phytoplankton growth was substantially greater under conditions of increased P availability. P effects on phytoplankton chlorophyll a concentrations were somewhat less dramatic. Under 'N-Poor' conditions, a 25 -fold increase in $\mathrm{P}$ resulted in a $42 \%$ increase in phytoplankton, while under 'N-Rich' conditions a 25 -fold increase in $\mathrm{P}$ pro- duced a $275 \%$ increase in phytoplankton abundance (Table 4). Thus, increased availability of $\mathrm{N}$ had a marked $(7 \times)$ effect on phytoplankton responses to $\mathrm{P}$ addition.

While both $N$ and P loading caused increases in algal biomass, these treatments resulted in decreased Potamogeton perfoliatus growth (mg dry wt shoot ${ }^{-1}$ $\mathrm{d}^{-1}$ ). Under 'P-Poor' conditions, a 25 -fold increase in $\mathrm{N}$ resulted in a $6 \%$ decline in growth, while under ' $\mathrm{P}$ Rich' conditions, the same $\mathrm{N}$ increase yielded a $16 \%$ decrease. Generally, $N$ treatment effects on new leaf production were even more pronounced (e.g. 25-fold $\mathrm{N}$ increase led to $30 \%$ decrease in leaf production under 'P-Rich' conditions). Effects of P additions were slightly greater than those for $\mathrm{N}$ enrichment, where a 25 -fold increase in $\mathrm{P}$ elicited a $13 \%$ decrease in plant growth under ' $\mathrm{N}$-Poor' conditions and a $58 \%$ decrease under 'N-Rich' conditions. Once again, the effects of both $\mathrm{N}$ and P loading on plant growth were far greater under 'P-Rich' and 'N-Rich' conditions, respectively.

No previous studies have examined the relative importance of $\mathrm{N}$ versus $\mathrm{P}$ for growth of epiphytes in estuaries. Pringle (1987), however, reported that periphyton growth in streams exhibited significant increases in response to P enrichment of the overlying water, and subsequently became $N$ limited. Moreover, these freshwater periphyton responses to inputs of $N$ plus $P$ were synergistic (Pringle 1987), similar to those exhibited by both epiphytic and planktonic algae in our study. Results of the present study are also consistent with previous reports of periodically varying conditions of both $\mathrm{N}$ and $\mathrm{P}$ for phytoplankton in brackish estuaries (Boynton et al. 1982, D'Elia et al. 1986). Furthermore, these results follow the pattern suggested by Caraco et al. (1987) for phytoplankton nutrient conditions in estuaries, with a mixture of $\mathrm{N}$ and $\mathrm{P}$ limitation at low to mid salinities 
In summary, growth of both epiphytic and phytoplanktonic algae in these brackish experimental estuarine systems responded strongly and significantly to increases in both $\mathrm{N}$ and $\mathrm{P}$. The relative responses of algal growth to $\mathrm{N}$ and $\mathrm{P}$ treatment (equivalent to 25 fold increases) were similar for both nutrients. Growth and biomass of the submersed plant, Potamogeton perfoliatus, declined significantly with increased inputs of both $\mathrm{N}$ and $\mathrm{P}$ and with the associated shading from accumulated algal standing stocks. Addition of P caused a relatively more pronounced reduction in plant production (58\%), however, than did equivalent additions of $\mathrm{N}(16$ to $30 \%)$. Effects of $\mathrm{N}$ additions were strongest when accompanied by parallel high inputs of $\mathrm{P}$, and conversely, effects of increased $\mathrm{P}$ inputs were greatest at High $N$ loading, suggesting that nutrient conditions in these microcosms were such that both $\mathrm{N}$ and $\mathrm{P}$ were potentially limiting for algal growth. Previous studies have concluded that nutrient ( $N$ and/or P) enrichment of brackish Chesapeake Bay waters has contributed substantially to the general decline of submersed vascular plants from this estuarine system (Kemp et al. 1983. Twilley et al. 1985). One implication of the present results is that management efforts to reduce eutrophication effects, including decreases in epiphyte and phytoplankton densities and improvements in associated light conditions, for restoration of submersed plants such as $P$. perfoliatus should consider reductions in inputs of both $\mathrm{N}$ and $\mathrm{P}$.

Acknowledgements. This research was supported by grants from US Geological Survey, Maryland Water Resources Research Center (No. 04-87, 88, 89) and by a grant from the State of Maryland Chesapeake Bay Trust. We are particularly indebted to Bill Dennison and Laura Murray for their contributions to the design and conduct of this research project. We also thank other students and colleagues, including Jane Caffrey, Marilyn Mayer, Rick Bartleson and Tom Randall, for their help with various aspects of data collection and analyses. Contribution No. 2412 of the Univ. of Maryland' System Center for Environmental and Estuarine Studies

\section{LITERATURE CITED}

Atkinson, M. J., Smith, S. V. (1983). C:N:P ratios of benthic marine plants. Limnol. Oceanogr. 28(3): 568-574

Barko, J. W., Smart, R. M. (1981). Comparative influences of light and temperature on the growth and metabolism of selected submersed freshwater macrophytes. Ecol. Monogr. 51: 219-235

Borum, J. (1985). Development of epiphytic communities on eelgrass (Zostera marina) along a nutrient gradient in a Danish estuary. Mar. Biol. 87: 211-218

Borum, J., Wium-Andersen, S. (1980). Biomass and production of epiphytes on eelgrass (Zostera marina L.) in the Øresund, Denmark. Ophelia, Suppl. 1: 57-64

Boynton, W. R., Kemp, W. M., Keefe, C. W. (1982). A comparative analysis of nutrients and other factors influencing estuarine phytoplankton production. In: Kennedy, V. S. (ed.)
Estuarine comparisons. Academic Press, New York, p. $69-89$

Bulthuis, D. A., Woelkerling, W. J. (1983). Biomass accumulation and shading effects of epiphytes on leaves of the seagrass, Heterozostera tasmanica, in Victoria, Australia. Aquat. Bot. 16: 137-148

Caffrey, J., Kemp, W. M. (1990). Nitrogen cycling in sediments with estuarine populations of Potamogeton perfoliatus and Zostera marina. Mar. Ecol. Prog. Ser. 66: 147-160

Cambridge, J. L., Chiffings, A. W., Brittan, C., Moore, L., McComb, A. J. (1986). The loss of seagrass in Cockburn Sound, Western Australia. II. Possible causes of seagrass decline. Aquat. Bot. 24: 269-285

Caraco, N., Tamse, A., Boutros, O., Valiela, I. (1987). Nutrient limitation of phytoplankton growth in brackish coastal ponds. Can. J. Fish. Aquat. Sci. 44: 473-476

Cattaneo, A., Kalff, J. (1986). The effect of grazer size on periphyton communities. Oecologia 69: 612-627

Correll, D. L. (1981). Nutrient mass balances for the watershed, headwaters intertidal zone, and basin of the Rhode River Estuary. Limnol. Oceanogr. 26(6): 1142-1149

D'Elia, C. F., Sanders, J. G., Boynton, W. R. (1986). Nutrient enrichment studies in a coastal plain estuary; phytoplankton growth in large-scale, continuous cultures. Can J. Fish. Aquat. Sci. 43: 397-406

den Hartog, C., Polderman, P. J. G. (1975). Changes in the seagrass populations of the Dutch Waddenzee. Aquat. Bot. 1: $141-147$

Dennison, W. C., Alberte, R. S. (1986). Photoadaptation and growth of Zostera marina L. (eelgrass) transplants along a depth gradient. J. exp. mar. Biol. Ecol. 98: 265-282

Duarte, C. M. (1990). Seagrass nutrient content. Mar. Ecol. Prog. Ser. 67: 201-207

Goldsborough, W. J., Kemp, W. M. (1988). Light responses of a submersed macrophyte: implications for survival in turbid tidal waters. Ecology 68(6): 1775-1786

Jupp, B. P., Spence, D. H. N. (1977). Limitations of macrophytes in a eutrophic lake, Loch Leven. II. Wave action, sediments, and waterfowl grazing. J. Ecol. 66: 431-446

Kemp, W. M., Lewis, M. R., Jones, T. W. (1986). Comparison of methods for measuring production by the submersed macrophyte Potamogeton perfoliatus L. Limnol. Oceanogr. 31: 1322-1334

Kemp, W. M., Twilley, R. R., Boynton, W. R. Stevenson, J. C., Means, J. C. (1983). The decline of submersed vascular plants in upper Chesapeake Bay: summary of results concerning possible causes. Mar. Technol. Soc. J. 17: $78-89$

Likens, G. E. (1975). Nutrient flux and cycling in freshwater ecosystems. In: Howell, F. G., Gentry, J. B., Smith, M. H. (eds.) Mineral cycling in southeastern ecosystems. U.S. Dept. Energy Confer. Ser. CONF-740513, NTIS, Springfield, VA

Lubbers, L., Boynton, W. R., Kemp, W. M. (1990). Variations in structure of estuarine fish communities in relation to abundance of submersed vascular plants. Mar. Ecol. Prog. Ser. 65: $1-14$

Neundorfer, J. V. (1990). Effects of nitrogen versus phosphorus additions to waters overlying estuarine populations of two submersed vascular plants. M.Sc. thesis, Univ. of Maryland, College Park

Nixon, S. W. (1987). Chesapeake Bay nutrient budgets: a reassessment. Biogeochemistry 4:77-90

Officer, C. B., Ryther, J. H. (1980). The possible importance of silicon in marine eutrophication. Mar. Ecol. Prog. Ser. 3: $83-91$

Orth, R. J., Moore, K. A. (1983). Chesapeake Bay: an unprec- 
edented decline in submerged aquatic vegetation. Science 222: $51-53$

Parsons, T R., Maita, Y., Lalli, C. M. (1984). A manual of chemical and biological methods for seawater analysis. Pergamon Press, New York

Parsons, T R., Takahashi, M., Hargrave, B. (1979). Biological oceanographic processes. Pergamon Press, Oxford

Pedersen, M. F. (1990). Nitrogen dynamics of eelgrass M.Sc. thesis, Univ. of Copenhagen, Hillerod

Phillips, G. L., Eminson, D., Moss, B. (1978). A mechanism to account for macrophyte decline in progressively eutrophicated freshwaters. Aquat. Bot. 4: 103-126

Porter, K. G., Feig, Y. S. (1980). The use of DAPI for identifying and counting aquatic microflora. Limnol. Oceanogr. 25(5): $943-948$

Pringle, C. M. (1987). Effects of water and substratum nutrient supplies on lotic periphyton growth: an integrated bioassay. Can. J. Fish. Aquat. Sci. 44:619-629

Redfield, A. C., Ketchum, B. H., Richards, F. A. (1963). The influence of organisms on the composition of sea-water. In: Hill, M. N. (ed.) The sea, Vol. 2. Wiley, New York, p. 26-77

Ryther, J. H., Dunstan, W. M. (1971). Nitrogen, phosphorus, and eutrophication in the coastal marine environment. Science 171. 1008-1013

Salisbury, F. B., Ross, C. W. (1985). Plant physiology. Wadsworth Publ., Beimont

Sand-Jensen, K., Borum, J. (1984). Epiphyte shading and its effect on photosynthesis and diel metabolism of Lobelia dortmanna L. during the spring bloom in a Danish lake. Aquat. Bot. 20: 109-119

Sand-Jensen, K., Sondergaard, M. (1981). Phytoplankton and epiphyte development and their shading effect on submerged macrophytes in lakes of different nutrient status. Int. Rev. ges. Hydrobiol. 66(4): 529-552

Schindler, D. W. (1977). The evolution of phosphorus limitation in lakes. Science 195: 260-262

Short, F. T., Davis, M. W., Gibson, R. A., Zimmermann, C. F. (1985). Evidence for phosphorus limitation in carbonate sediments of the seagrass Syringodium filiforme. Estuar. coast. Shelf Sci. 20: $419-430$

This article was presented by G. W. Thayer, Beaufort, N. Carolina, USA
Silberstein, K., Chiffings, A. W., McComb, A. J. (1986). The loss of seagrass in Cockburn Sound, Western Australia. III. The effect of epiphytes on productivity of Posidonia australis Hook F. Aquat. Bot. 24: 355-371

Spence, D. H. N. (1975). Light and plant response in fresh water. In: Evans, G. C., Bainbridge, R., Rackham, O. (eds.) Light as an ecological factor. Blackwell Sci. Publ., Oxford, p. $93-133$

Staver, K. (1984). Responses of epiphytic algae to nitrogen and phosphorus enrichment and effects on productivity of the host plant, Potamogeton perfoliatus L., in estuarine waters. M.Sc. thesis, Univ. of Maryland, College Park

Stevenson, J. C., Confer, N. M. (1978). Summary of available information on Chesapeake Bay submerged vegetation. U.S. Dept. Int. FWS/OBS-78/66. NTIS, Springfield VA

Strickland, J. D. H., Parsons, T. R. (1972). A practical handbook of seawater analysis. Bull. Fish. Res. Bd Can. 167

Twilley, R. R., Ejdung, G., Romare, P., Kemp, W. M. (1986). A comparative study of decomposition, oxygen consumption and nutrient release for selected aquatic plants occurring in an estuarine environment. Oikos 47: $190-198$

Twilley, R. R., Kemp, W. M., Staver, K. W., Stevenson, J. C. Boynton, W. R. (1985). Nutrient enrichment of estuarine submersed vascular plant communities. I. Algal growth and effects on production of plants and associated communities. Mar. Ecol. Prog. Ser. 23: 179-191

Van Montfrans, J., Wetzel, R. L., Orth, R. J. (1984). Epiphytegrazer relationships in seagrass meadows: consequences for seagrass growth and production. Estuaries $7(4 \mathrm{~A})$ : 289-309

Ward, L. G., Kemp, W. M., Boynton, W. R. (1984). The influence of waves and seagrass communities on suspended sediment dynamics in an estuarine embayment. Mar. Geol 59: 85-103

Zieman, J. C., Wetzel, R. G. (1980). Productivity in seagrasses: methods and rates. In: Phillips, D. C., McRoy, C. P. (eds.) Handbook of seagrass biology: an ecosystem perspective. Garland STPM. New York, p. 87-118

Manuscript first received: April 20, 1992

Revised version accepted: December 28, 1992 